\title{
Assessing land use by cattle in heterogeneous environments
}

\author{
Uso do espaço por bovinos em ambientes heterogêneos
}

\begin{abstract}
Aline Cristina Sant'Anna ${ }^{I}$ Mateus José Rodrigues Paranhos da Costa ${ }^{I^{*}}$ Adriano Gomes Páscoa ${ }^{\text {II }}$ Lívia Carolina Magalhães Silva ${ }^{\text {III }}$ Jens Jung ${ }^{\text {IV }}$
\end{abstract}

\section{- NOTE -}

\section{ABSTRACT}

The aim of this note is to describe preliminary results on assessment of land use by cattle, obtained in a pilot study using Geographic Information System (GIS). The research was carried out on a semi-natural pasture in Sweden, where the geographic positions of one cow were recorded during 25 consecutive days during summer. The cow, wearing a GPS collar, was integrated in a herd of 53 Hereford cattle. Each location point registered for the animal was considered as a sampling unit $(N=3,097)$. The spatial distribution of ground declivity, water sources, cattle tracks, and classes of woody vegetation cover (forest, grassland with trees and open grassland) were recorded. The storage, processing and data analysis were carried out using the Idrisi and GS+ softwares. Three occupation zones were identified in function of the variation in the space used by the animal, which were occupied in a cyclical pattern; with the animal moving from one zone to another in cycles of five days. It was also clear that the cattle distribution in the area was neither random nor uniform, and it was affected by environmental characteristics that act as conditioners on its distribution. These preliminary results suggest that definition of zones of occupation and the environmental conditioners are promising tools to understand the land use by cattle.

Keywords: cattle, behavior, GeographicInformation System,pasture.

\section{RESUMO}

O objetivo desta nota é apresentar resultados preliminares sobre a avaliação do uso do espaço por bovinos, obtidos em um estudo piloto com o uso de Sistema de Informação Geográfico. O trabalho foi realizado em uma pastagem seminatural na Suécia, onde as posições geográficas de uma vaca foram registradas durante 25 dias consecutivos no verão. $O$ animal, equipado com colar GPS, fazia parte de um rebanho de 53 bovinos da raça Hereford. Cada ponto de localização registrado

\begin{abstract}
foi considerado como uma unidade amostral (N=3.097). As distribuições espaciais do bovino, da declividade do terreno, das fontes de água, das trilhas formadas pelo gado e das classes de cobertura vegetal (floresta, pastagem com árvores e pastagem aberta) foram registradas. O processamento e análise de dados foram feitos com uso dos softwares Idrisi e GS+. Três zonas de ocupação foram identificadas em função da variação no uso do espaço pelo animal, caracterizando um padrão cíclico de ocupação, com deslocamento de uma zona para outra a cada cinco dias. Ficou claro também que a distribuição do bovino na área não foi aleatória nem uniforme, sendo influenciada por características ambientais, que atuaram como condicionadores do uso do espaço. Estes resultados preliminares sugerem que a definição de zonas de ocupação e de condicionadores ambientais são ferramentas promissoras para esclarecer o uso do espaço pelo gado.
\end{abstract}

Palavras-chave: bovinos, comportamento, pastagem, Sistema de Informação Geográfica.

Extensive cattle breeding have brought concern about the conservation of semi-natural areas. If, on one hand, the presence of cattle in these areas can increase the risks of soil erosion, water pollution and loss of biodiversity (CARVALHO \& BATELLO, 2009), on the other hand, the presence of cattle can increase plant species richness (PYKÄLÄ, 2003) and reduce the risk of wildfires (EVLAGON et al., 2012). Such impacts depend on the particularities of the environment and on the patterns of land use by the animals.

There are evidences that spatial distribution of cattle in an area is not random, being dependent of

'Departamento de Zootecnia, Faculdade de Ciências Agrárias e Veterinária (FCAV), Universidade Estadual de São Paulo (UNESP), Via de Acesso Prof. Paulo D. Castellane, km 5, 14884-900, Jaboticabal, SP, Brasil. E-mail: mpcosta@fcav.unesp.br.*Corresponding author. "BEA Consultoria e Treinamento, Jaboticabal, SP, Brasil.

IIIPrograma de Pós-graduação em Zootecnia, FCAV, UNESP, Jaboticabal, SP, Brasil.

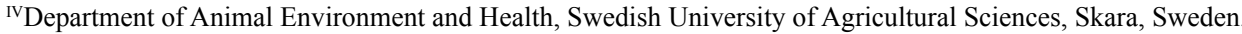
Received 11.28.13 Approved 07.29.14 Returned by the author 10.09.14 CR-2013-1576.R1 
both biotic and abiotic factors, such as quantity and quality of forage, shade availability, water source location and ground declivity (GANSKOPP et al., 2000). The assessment of these effects can be done by applying Geographic Information System (GIS) and geostatistical methods. The aim of this note is to describe preliminary results on the assessment of land use by cattle, obtained in a pilot study using GIS.

The use of animals was approved by the Animal Ethics Committee of Swedish University of Agricultural Sciences (Protocol Dnr 40-2004). The study was conducted in a semi-natural area of $63.63 \mathrm{ha}$, located in southwest Sweden $\left(58^{\circ} 25^{\prime} 33^{\prime \prime} \mathrm{N}\right.$ and $\left.13^{\circ} 50^{\prime 2} 29^{\prime \prime} \mathrm{E}\right)$. This area is part of the Nature Reserve Rånna Ryd, and consists of 42.87ha of open grassland $(67.37 \%), 15.89$ ha of forests $(24.97 \%)$ and 4.87 ha of grassland with isolated trees $(7.66 \%)$. One cow in a group of 53 Hereford animals (one bull, 26 cows, and 26 suckler calves) was equipped with a GPS collar (GPS Plus-2, Vectronic Aerospace GmbH, Berlin) and had its geographic position recorded every $5 \mathrm{~min}$ from 20 July to 14 August 2007, during this period the animals had continuous access to the whole area. Sample size was defined by every recorded animal location point $(\mathrm{N}=3,097)$. As cattle exhibit gregarious social behavior, with synchronization of activities, it is reasonable to assume that the location of one cow can predict the location of the group at a given time. To assess the cow spatial location throughout the day, the 24 hours was equally divided into four periods: night (23 to $5 \mathrm{~h}$ ), morning (5 to $11 \mathrm{~h}$ ), afternoon (11 to $17 \mathrm{~h}$ ) and evening (17 to $23 \mathrm{~h}$ ).

A GIS was used to store, process and analyze data, applying the Idrisi software version 15 (Clark Labs, 2006) and GS + (Gamma Design Software, 2000). Four environmental characteristics were assessed as potential conditioners of the animal distribution: cattle tracks, ground declivity, woody vegetation cover and water sources. Maps for all the environmental characteristics, animal location (location points) and animal distribution (location points per area) were built, as follow: i) animal locations, using the module HISTO (Idrisi) to count the number of location points for each period of the day; ii) animal spatial distribution, using the module EXTRACT (Idrisi) to calculate the number of animal location points for each quadrant with $20 \mathrm{~m}$ of radii (in occurrences per $1,256 \mathrm{~m}^{2}$ ); iii) the spatial location of water sources, and cattle tracks were recorded using the active $\log$ function of a handheld GPS (E-trex Vista $\mathrm{HCx}$, Garmin Internat. Inc., Olathe, KA), and the maps were built using the module DISTANCE (Idrisi) to calculate the distances from each point in the pasture to the closest water source or cattle track; iv) map of ground declivity, using module SLOPE (Idrisi); v) map of vegetation cover, using a geo-referenced aerial photo (from http://www.eniro. $\mathrm{se} /$ ), the differences of color in the picture enabled the classification in: open grasslands (without trees), forests (continuous areas with more than 1 ha covered by trees), and grassland with trees (when the trees cover areas with less than 1 ha) (Figure 1A).

The definition of zones of use was based on the cow's distribution throughout the study period, combined with the presence of water source and forest. The zones of use had different sizes $(33.60,10.50$ and 20.42ha for Zones 1, 2, and 3, respectively), but all of them had at least one water point and one area defined as forest (a continuous area with more than 1 ha covered by trees), the salt block was located at Zone 1 (Figure 1B). The numbers of location points for each zone were obtained using the module HISTO (Idrisi). As the zones had different sizes, we calculated the daily ratio of location points per hectare and the ratios were compared among the three zones of occupation, using the Kruskal-Wallis test $(\mathrm{H})$.

To assess the effect of environmental characteristics on spatial distribution of the animal, multiple spatial regression was used through ldrisi MULTIREG module. The following equation was obtained: Yijklm $=\mu+\alpha i+\gamma j+\delta k+\varphi l+\varepsilon i j k l m$, where: Yijkm = dependent variable (cow distribution); $\mu=$ overall mean; $\alpha i=$ distribution of trees (we used the sum of 'forests' and 'grassland with trees'); $\gamma j=$ declivity; $\delta k=$ distribution of tracks; $\varphi l=$ distribution of water sources; cijklm = random error.

The occupancy rate (in percentage of location points) of open grassland was higher than areas covered by forest and grassland with trees in all periods of the day (Table 1). The use of forest occurred more often during night and less during afternoon. With the exception of night period, the cow occupied sites with slopes lower than the average of the area (which was $12.90^{\circ}$ ). It has become evident the low occupancy rate within the forest areas, and it was predominantly used at night. The cattle occupancy of forest during nighttime raised an important methodological issue - the efficiency of GPS collars decreased under the canopy of trees, accounting for almost 50\% fewer records obtained overnight. Studies using GPS collars under trees have to be controlled for the lower recording efficiency under this condition, as reported by AGOURIDIS et al. (2004), who observed that GPS collars produce 2.5 times greater errors when under tree cover than in open grassland. 


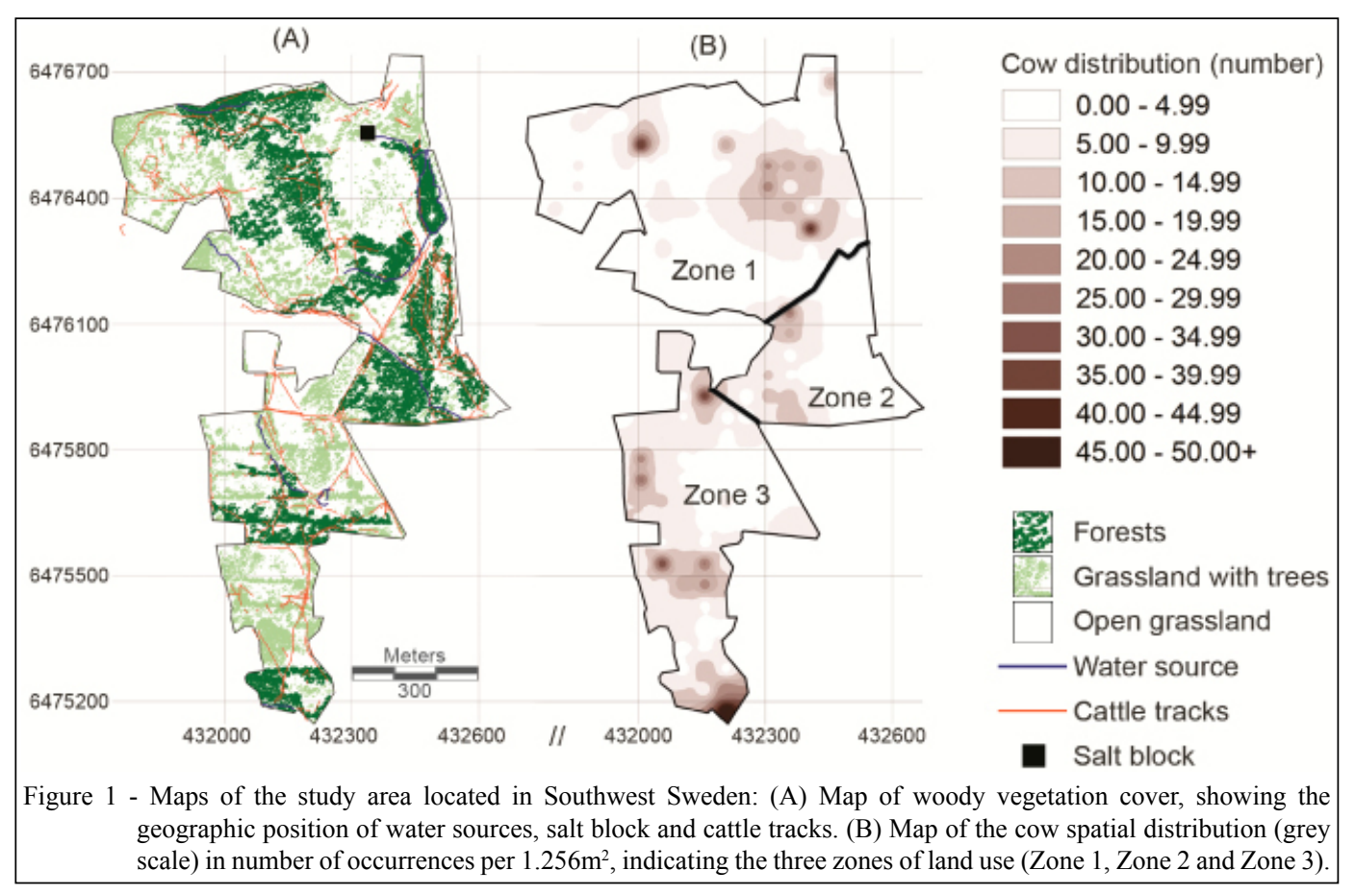

The cow's spatial distribution varied over the study area, from sites of intense use (named as hot spots), with more than 35 occurrences per $1,256 \mathrm{~m}^{2}$, to sites with rare occupation, less than five occurrences per $1,256 \mathrm{~m}^{2}$ (Figure 1B). The environmental characteristics explained $5.53 \%$ of variability in the cow's spatial distribution $(\mathrm{R}=0.24, \mathrm{P}<0.01)$, as indicated by the following equation: $Y=51.09+1.92 *$ trees $-0.33 *$ declivity $+0.23 *$ tracks $+0.08 *$ water sources. Although the environmental characteristics analyzed had shown only moderate ability to predict the spatial distribution of the animal in the area, it was evident that woody vegetation cover and ground declivity were the most influential traits. This result is in agreement with other study, indicating that cattle avoid areas with higher declivity as strategy to reduce energy expenditure (GANSKOPP et al., 2000).
It was possible to define tree zones of use, with different occupancy rates (Kruskal-Wallis test, $\mathrm{H}=18.37, \mathrm{P}<0.01)$. The Zone 2 had the lowest daily occupation (25.71 points/ha), followed by Zone 1 (31.78 points.ha ${ }^{-1}$ ), and Zone 3 exhibited the highest occupancy rate $\left(65.43\right.$ points.ha $\left.{ }^{-1}\right)$. The cow moved through the study area in a regular pattern, with a temporal cycle of occupation, using the three zones in a five days cycle. Based on this we assumed that the cow moved between Zone 1 and 3, where it preferred to stay, using Zone 2 as a transitional site. This trend was also reported by BAILEY et al. (1990), who found that cattle rarely occupied the same area for more than two consecutive days, and their location in the morning on a specific day depended on the occupation in the morning of the previous day. This characteristic may reflect an evolutionary strategy that increases the grazing efficiency.

Table 1 - Number of sampling cow's location points according to the period of the day and respective percentages of samples obtained for each class of woody vegetation cover (open grassland, forest, and grassland with trees), and means ( \pm standard deviations) of distance from the nearest cattle track and ground declivity for the sites occupied by the animal.

\begin{tabular}{lcccccc}
\hline Period of the day & $\begin{array}{c}\text { Cow's sampling } \\
\text { points (N) }\end{array}$ & Open grassland (\%) & Forest (\%) & $\begin{array}{c}\text { Grassland with } \\
\text { trees (\%) }\end{array}$ & $\begin{array}{c}\text { Distance from the } \\
\text { nearest cattle track (m) }\end{array}$ & Ground declivity $\left({ }^{\circ}\right)$ \\
\hline Night & 420 & 68 & 28 & 4 & $20.25(17.67)$ & $16.96(17.54)$ \\
Morning & 879 & 81 & 11 & 8 & $18.90(17.23)$ & $10.43(12.52)$ \\
Afternoon & 955 & 80 & 9 & 11 & $26.20(21.32)$ & $8.44(9.40)$ \\
Evening & 843 & 79 & 17 & 4 & $22.20(19.63)$ & $10.68(12.87)$ \\
24 hours period & 3097 & 79 & 14 & 7 & 29.44 & 11.62 \\
\hline
\end{tabular}


These preliminary results indicate that cattle define a temporal pattern of land use, characterized by a cyclic rhythm of occupation. Also, cattle distribution in the area was neither random nor uniform, being affected by environmental traits, which act as land use conditioners. Although we recommend caution when generalizing these results, since we used one cow sample size, they bring valuable information that can be used to design future research on the same subject and offer ideas about cattle land use.

\section{ACKNOWLEDGMENTS}

Appreciation is expressed to Anna Lundberg and Linda Keeling, SLU. Also, we thank the Swedish Board of Agriculture for funding (process number: 31-7070/07).

\section{REFERENCES}

AGOURIDIS, C.T. et al. Suitability of a GPS collar for grazing studies. American Society of Agricultural Engineers, v.47, p.1321-1329, 2004. Available from: <http://shs.tamu.edu/docs/ lshs/end-notes/suitability $\% 20$ of $\% 20 \mathrm{a} \% 20 \mathrm{gps} \% 20$ collar $\% 20$ for $\% 20$ grazing $\% 20$ studies-0301967361/suitability\%20of $\% 20$ a $\% 20$ gps $\% 20$ collar $\% 20$ for $\% 20$ grazing $\% 20$ studies.pdf $>$. Accessed: Aug. 28, 2006
BAILEY, D.W. et al. Sequential analysis of cattle location: Dayto-day movement patterns. Applied Animal Behaviour Science, v.25, p.137-148, 1990. Available from: $<$ http://www.sciencedirect. com/science/article/pii/016815919090076P $>$. Accessed: Jul. 11, 2013. doi: 10.1016/0168-1591(90)90076-P.

CARVALHO, P.C.F.; BATELLO, C. Access to land, livestock production and ecosystem conservation in the Brazilian Campos biome: the natural grasslands dilemma. Livestock Science, v.120, p.158-162, 2009. Available from: <http://www.sciencedirect.com/ science/article/pii/S1871141308001285>. Accessed: Jul. 8, 2013. doi: 10.1016/j.livsci.2008.04.012.

EVLAGON, D. et al. Estimating normative grazing capacity of planted Mediterranean forests in a fire-prone environment. Agriculture, Ecosystems \& Environment, v.155, p.133-141, 2012. Available from: <http://www.sciencedirect.com/science/ article/pii/S0167880912001521>. Accessed: Jul. 11, 2013. doi: 10.1016/j.agee.2012.04.010

GANSKOPP, D. et al. Least-effort pathways: a GIS analysis of livestock trails in rugged terrain. Applied Animal Behaviour Science, v.68, p.179-190, 2000. Available from: <http://www. sciencedirect.com/science/article/pii/S0168159100001015>. Accessed: Oct. 18, 2006. doi: 10.1016/S0168-1591(00)00101-5.

PYKÄLÄ, J. Effects of restoration with cattle grazing on plant species composition and richness of semi-natural grasslands. Biodiversity and Conservation, v.12, p.2211-2226, 2003. Available from: <http://link.springer.com/article/10.1023 /A:1024558617080>. Accessed: Nov. 15, 2006. 